\title{
Magdalena Gawin, Spór o równouprawnienie kobiet (1864-1919), wyd. Instytut Historii PAN, Polskie Towarzystwo Historyczne, Wydawnic- two Neriton, Warszawa 2015, ss. 346.
}

$\mathrm{M}$ agdalena Gawin, warszawska historyczka związana z Instytutem Historii Polskiej Akademii Nauk, badawczo zajmująca się historią idei, ruchów międzynarodowych i polską kulturą polityczną XX w., w najnowszej pracy podjęła wątek równouprawnienia kobiet.

Naukowej analizie, w kontekście ruchu emancypacyjnego, Autorka poddała idee oraz przekonania dziesięciu postaci. Wybrani przez M. Gawin działacze, pisarze oraz politycy symbolizowali główne nurty ideologiczne epoki XIX wieku - socjalizm niepodległościowy, nacjonalizm, liberalizm, chrześcijańską demokrację i feminizm.

Praca poprzedzona wprowadzeniem, składa się z dziesięciu zasadniczych rozdziałów, podsumowania, indeksu nazwisk oraz spisu ilustracji. Pierwszy z rozdziałów zawiera charakterystykę głównych poglądów Elizy Orzeszkowej w kontekście emancypacji kobiet. Tło ich opisu stanowi krótki rys biograficzny pisarki. Na przykładzie Marty Autorka ukazała problem edukacji kobiet oraz istniejący w historiografii spór, w ramach którego zarzuca się E. Orzeszkowej, że ,,jej idea” emancypacji wykazywała znamiona ,samoograniczającej się”.

W dalszej kolejności Autorka analizie poddała poglądy Marii Konopnickiej. Filozofia stworzona przez autorkę Roty, według M. Gawin, uosabiała naukę oraz racjonalizm. M. Konopnicka w swoim programie optowała zatem za dostępem kobiet do studiów uniwersyteckich. Autorka Sporu o równouprawnienie... postawiła tezę, iż usilne nawoływanie pozytywistki do podjęcia studiów, wynikało z odebranej przez nią edukacji, która nigdy nie została usystematyzowana, „ani poddana rygorom myślenia naukowego”. Wykształcenie, w przekonaniu M. Konopnickiej, miało uchronić kobiety przed stanem, który według niej nie był naturalny - przed małżeństwem.

W trzecim rozdziale historyczka zaprezentowała poglądy Marii Rodziewiczówny. Autorka Wrzosu, podobnie jak M. Konopnicka oraz E. Orzeszkowa, swoje poglądy wyrażała na łamach ,Świtu” oraz wydawanych dzieł. W przypadku M. Rodziewiczówny pierwszym z nich była Farsa Panny Heni, tytułowa bohaterka marzyła o ukończeniu studiów medycznych. Pisarka podniosła zatem taki

${ }^{1}$ M. Gawin, Spór o równouprawnienie kobiet (1864-1919), Warszawa 2015, s. 28. 
sam problem w kwestii pozycji kobiety w XIX w., jak E. Orzeszkowa. Ponadto, zdaniem pisarki, emancypacji kobiet przeszkadzał mizoginizm. Także w tej części pracy M. Gawin - za Barbarą Szargot, przedstawiła toczącą się dyskusję pomiędzy E. Orzeszkową, a M. Rodziewiczówną. Autorki czyniły to za pomocą bohaterek swoich dzieł. Nie zaprezentowała jednak swojego stanowiska w tej kwestii.

Następnie Autorka naukowej analizie poddała poglądy Pauliny Kuczalskiej-Reinschmit. W ich kontekście wskazała na wiele nieścisłości oraz niejasności w biografii feministki. P. Kuczalska-Reinschmit związana była z „Tygodnikiem Ilustrowanym”, „Kurierem Warszawskim” oraz „Kurierem Codziennym”. Na polu publicystycznym, głosząc swoje poglądy w kwestii pozycji XIX-wiecznej kobiety, zaczęła działać - podobnie jak E. Orzeszkowa po rozstaniu z mężem.

W piątym rozdziale, $M$. Gawin przyjrzała się poglądom marksisty i teoretyka socjalizmu niepodległościowego, Kazimierza Kelles-Krauzego. W latach 90. XIX w. traktowano bowiem problem równouprawnienia kobiet oraz socjalizm jako nierozerwalną całość. W tym miejscu warszawska historyczka odwołała się także do Jana Czyńskiego, Karola Marksa oraz Augusta Bebela. Wskazała, iż w lewicowej myśli socjalistycznej to właśnie pierwszy z nich był prekursorem równouprawnienia kobiet. Badaczka w tym miejscu zwróciła uwagę na to, że wydany przez Karola Marksa oraz Fryderyka Engelsa Manifest Komunistyczny negował istniejący w XIX w. model małżeństwa. Ponadto, według M. Gawin, K. Kelles-Krauz kontestował mieszczańską obyczajowość w kontekście modelu rodziny, opierając się między innymi na młodopolskim dziele Gabrieli Zapolskiej pt. Moralność pani Dulskiej.

Rozdział szósty, historyczka poświęciła Bolesławowi Prusowi. Na łamach „Steru” o autorze Lalki P. Kuczalska-Reinschmit napisała, że był rzecznikiem poprawy doli kobiet i ich równouprawnienia ${ }^{2}$. Autorka pracy wskazała, iż B. Prus zauważał palącą potrzebę redefinicji roli i pozycji kobiety w XIX-wiecznym społeczeństwie. W tym upatrywał warunków osiągnięcia wyższego poziomu cywilizacyjnego społeczeństwa. Także i on zwracał szczególną uwagę na wykształcenie kobiet. Twierdził, iż te także powinny zajmować się arytmetyką, astronomią oraz zoologią. Jednocześnie jednak zarzucał kobietom z wyższych sfer, że samodzielnie nie dbają o dom, a zatrudniają w tym celu lokai, nianie i kucharki. O pozycji kobiety Aleksander Głowacki mówił także za pośrednictwem swoich bohaterów. W tym kontekście wypowiadali się między innymi Ignacy Rzecki oraz Stanisław Wokulski, bohaterowie panoramicznej powieści B. Prusa.

W kolejnym rozdziale, M. Gawin odniosła się do poglądów Gabrieli Zapolskiej: ,postanowiłam przedstawić rozbieżność w pisarstwie Zapolskiej oraz przyjrzeć się z bliska jej wiedzy i niewiedzy na temat idei emancypacji kobiet”з. W pierwszej kolejności odniosła się do listu, jaki młodopolska pisarka opubli-

${ }^{2}$ M. Gawin, $d z$. cyt.. s. 185.

3 Tamże, s. 201. 
kowała na łamach warszawskiej prasy. Według Autorki pracy, była to krytyka równouprawnia kobiet. List, według historyczki, był o tyle ważny, że wyszedł spod pióra literatki związanej z ruchem emancypacyjnym, jego sojuszniczki. Generalnie w kwestii równouprawnienia kobiet G. Zapolska stała na stanowisku, że przeznaczeniem i powołaniem kobiety jest praca na rzecz harmonijnego życia rodzinnego, a nie publicznego. Pisarka w kontekście wejścia kobiety w sferę życia publicznego widziała konflikt pomiędzy ich naturalnym powołaniem jako matki oraz żony, a tym czego kobiety chciały. Ponadto praca zarobkowa kobiet była postrzegana przez G. Zapolską w kategoriach zagrożenia ze strony mężczyzn. Według nowelistki bowiem, między kobietą a mężczyzną, istniała tylko namiętność. Nigdy zaś przyjaźń.

Siódmy rozdział pracy badaczka poświęciła działaczom Narodowej Demokracji, Romanowi Dmowskiemu oraz Zygmuntowi Balickiemu. Twórca polskiego nacjonalizmu stał na stanowisku, że emancypacja kobiet jest kwestią mało ważną. Obojętny na ten problem pozostawał także Z. Balicki. W jednej z prac, w rozdziale o systemach wyborczych, nie podjął kwestii praw wyborczych kobiet. Politycy stali zatem na stanowisku, iż fundamentów starego porządku społecznego nie należy niszczyć. M. Gawin w tym miejscu podjęła się próby omówienia przyczyn takiego podejścia polityków do kwestii równouprawnienia kobiet. Zdaniem historyczki była ona warunkowana trzema czynnikami: politycznymi, modernizacyjnymi i biograficznymi.

Przedostatni rozdział monografii został poświęcony między innymi postawom drugiej żony Józefa Piłsudskiego, Aleksandry Szczerbińskiej. M Gawin mocno wyartykułowała dzieciństwo żony Naczelnika, wskazując na samotność oraz apodyktyczną postawę babki. Pensja, małżeństwo i opieka nad dziećmi nie znajdowały się w kręgu jej zainteresowań. A. Szczerbińska działała w inteligenckim środowisku socjalistów. Badaczka jest zdania, że poprzez przyjętą przez socjalistkę postawę, kobieta optowała za równouprawnieniem. Jej zdaniem bowiem wybór opcji niepodległościowej nie był odrzuceniem tego postulatu, a wyborem drogi w sposób najpełniej wiodący do emancypacji kobiet. W rozdziale tym Autorka nieco miejsca poświęciła także postaci Marii Dąbrowskiej.

$\mathrm{W}$ ostatnim z rozdziałów - $W$ stronę równouprawnienia - Autorka scharakteryzowała zmianę postawy wobec emancypacji czołowych polityków II Rzeczypospolitej, Józefa Piłsudskiego oraz Ignacego Daszyńskiego. W kilku słowach odniosła się także do postawy duchowieństwa. W tym kontekście przytoczyła między innymi poglądy księdza Karola Niedziałkowskiego stojącego na stanowisku, że chrześcijaństwo nie tylko nie stało na przeszkodzie równouprawnienia kobiet, ale było ono możliwe właśnie dzięki niemu. Czasy powojenne Autorka postrzega w kategoriach szansy dla kobiet; upatruje ją między innymi w dostępie do studiów wyższych. 
Warszawska badaczka przeszłości wnikliwie prześledziła rozwój emancypacyjnej idei kobiet. Uczyniła to metodą biograficzną. Punktem wyjścia dla jej rozważań były biografie oraz twórczość działaczy. Nie skupiła się na jednym środowisku - na przykład tylko pisarek, ale analizie poddała także poglądy polityków. Pozostawione przez działaczy pamiętniki, dzienniki, powieści, listy oraz artykuły prasowe stanowią bazę źródłową monografii.

Z poczynionych badań, według $\mathrm{M}$. Gawin wynika, że niezależnie od orientacji ideologicznej, poglądy na równouprawnienie kobiet skupiały się wokół rozmaitych wartości - na przykład równości i sprawiedliwości.

Praca M. Gawin jest obecnie najświeższą publikacją rodzimej historiografii podejmującą ten wątek przeszłości. Jest monografią interesującą i oryginalną. Podjętą problematyką nie tylko wpisuje się w szeroko rozumiane zagadnienie historii kobiet, ale i w badania historii idei.

Tytułowy spór o równouprawnienie, został zaprezentowany w monografii z różnych stanowisk ideowych i przez pryzmat rozmaitych postaw. Autorka starała się udowodnić, że wiele było dróg i koncepcji emancypacji kobiet w polskiej przestrzeni publicznej drugiej połowy wieku XIX. Zaprezentowana przez M. Gawin dyskusja ideowa daje możliwości dalszych rozważań dotyczących równouprawnienia kobiet i stanowi ciekawą propozycję badawczą do poszukiwań kolejnych odsłon dyskursu emancypacyjnego. 